\title{
Deglacial variability in the surface return flow of the Atlantic meridional overturning circulation
}

\author{
Rosemarie E. Came, ${ }^{1,2}$ Delia W. Oppo, ${ }^{3}$ William B. Curry, ${ }^{3}$ and Jean Lynch-Stieglitz ${ }^{4}$ \\ Received 9 March 2007; revised 14 October 2007; accepted 13 November 2007; published 29 March 2008.
}

[1] Benthic foraminiferal $\mathrm{Cd} / \mathrm{Ca}$ from a Florida Current sediment core documents the history of the northward penetration of southern source waters within the surface return flow of the Atlantic meridional overturning circulation (AMOC). Cd seawater estimates $\left(\mathrm{Cd}_{\mathrm{W}}\right)$ indicate that intermediate-depth southern source waters crossed the equator and contributed to the Florida Current during the Bølling-Allerød warm period of the last deglaciation, consistent with evidence of only a modest $\mathrm{AMOC}$ reduction compared to today. The $\mathrm{Cd}_{\mathrm{W}}$ estimates also provide the first paleoceanographic evidence of a reduction in the influence of intermediate-depth southern source waters within the Florida Current during the Younger Dryas, a deglacial cold event characterized by a weak North Atlantic AMOC. Our results reveal a close correspondence between the northward penetration of intermediate-depth southern source waters and the influence of North Atlantic Deep Water, suggesting a possible link between intermediate-depth southern source waters and the strength of the Atlantic AMOC.

Citation: Came, R. E., D. W. Oppo, W. B. Curry, and J. Lynch-Stieglitz (2008), Deglacial variability in the surface return flow of the Atlantic meridional overturning circulation, Paleoceanography, 23, PA1217, doi:10.1029/2007PA001450.

\section{Introduction}

[2] Variations in the strength of the Atlantic meridional overturning circulation (AMOC) and its associated northward heat transport are believed to have affected climate of the last deglaciation. Decreases in the strength of the AMOC may have caused reductions in the amount of heat transported by the surface ocean to the North Atlantic, thereby cooling the high northern latitudes [Broecker et al., 1985]. Today, much of the northward moving surface return flow of the AMOC originates as thermocline and intermediate water in the South Atlantic [Schmitz and McCartney, 1993], leading to the prediction that past decreases in the intensity of overturning were accompanied by reduced northward penetration of these waters into the North Atlantic [Lynch-Stieglitz et al., 1999].

[3] Oceanic nutrient distributions can be used to trace changes in ocean water mass geometry. By contrast with nutrient-depleted North Atlantic water masses, Southern Ocean water masses are nutrient-enriched, and their presence in the North Atlantic can be monitored using nutrient tracers, such as $\delta^{13} \mathrm{C}$ and $\mathrm{Cd} / \mathrm{Ca}$ [Boyle, 1988; Boyle and Keigwin, 1982; Curry et al., 1988; Curry and Lohmann, 1982; Duplessy et al., 1988]. In the modern ocean, a correlation exists between seawater $\mathrm{Cd}$ concen-

\footnotetext{
${ }^{1}$ Massachusetts Institute of Technology/Woods Hole Oceanographic Institution Joint Program in Oceanography, Woods Hole, Massachusetts, USA.

${ }^{2}$ Now at Division of Geological and Planetary Sciences, California Institute of Technology, Pasadena, California, USA.

${ }^{3}$ Department of Marine Geology and Geophysics, Woods Hole Oceanographic Institution, Woods Hole, Massachusetts, USA.

${ }^{4}$ School of Earth and Atmospheric Sciences, Georgia Institute of Technology, Atlanta, Georgia, USA.
}

Copyright 2008 by the American Geophysical Union. 0883-8305/08/2007PA001450\$12.00 trations $\left(\mathrm{Cd}_{\mathrm{W}}\right)$ and seawater $\mathrm{PO}_{4}$ concentrations. Because $\mathrm{Cd}$ is incorporated into the $\mathrm{CaCO}_{3}$ tests of benthic foraminifera in direct proportion to the $\mathrm{Cd}$ concentration in the water in which the tests calcify, the $\mathrm{Cd} / \mathrm{Ca}$ ratio of foraminiferal tests can be used as an indicator of $\mathrm{Cd}_{\mathrm{W}}$ (and thus $\left.\mathrm{PO}_{4}\right)$ at the time the tests grew [Hester and Boyle, 1982]. The oceanic $\delta^{13} \mathrm{C}$ distribution is the result of the isotopic fractionation of carbon associated with photosynthesis, which favors ${ }^{12} \mathrm{C}$ over ${ }^{13} \mathrm{C}$. The remineralization at depth of low $\delta^{13} \mathrm{C}$ organic material produces a negative correlation between oceanic $\delta^{13} \mathrm{C}$ and $\mathrm{PO}_{4}$ [Kroopnick, 1985]. Like $\mathrm{Cd}_{\mathrm{W}}$, the oceanic $\delta^{13} \mathrm{C}$ signal is recorded in the tests of benthic foraminifera, making carbonate $\delta^{13} \mathrm{C}$ a useful tool in the reconstruction of paleonutrient distributions.

[4] Nutrient evidence from the last glacial suggests that a reduction in the influence of North Atlantic Deep Water (NADW) was associated with a corresponding increase in the influence of Glacial North Atlantic Intermediate Water (GNAIW) [Boyle and Keigwin, 1987; Duplessy et al., 1988; Marchitto et al., 2002; Oppo and Lehman, 1993]. Many studies have confirmed this glacial subsurface geometry of GNAIW overlying waters of southern origin, but the northward penetration of Antarctic Intermediate Water (AAIW) during the last glacial is poorly constrained [Curry and Oppo, 2005]. Likewise, while it is clear that the influence of NADW in the deep Atlantic was reduced during the Younger Dryas abrupt cooling event (approximately 13-11.5 ka B.P.) [Boyle and Keigwin, 1987], the response of intermediate-depth water masses such as North Atlantic Intermediate Water and AAIW is uncertain [Came et al., 2003; Marchitto et al., 1998; Rickaby and Elderfield, 2005; Zahn and Stüber, 2002]. For example, nutrient evidence from the intermediate-depth subtropical Atlantic suggests an increase in the influence of NAIW during the Younger Dryas [Marchitto et al., 1998], while evidence from the intermediate-depth high-latitude North Atlantic may indi- 


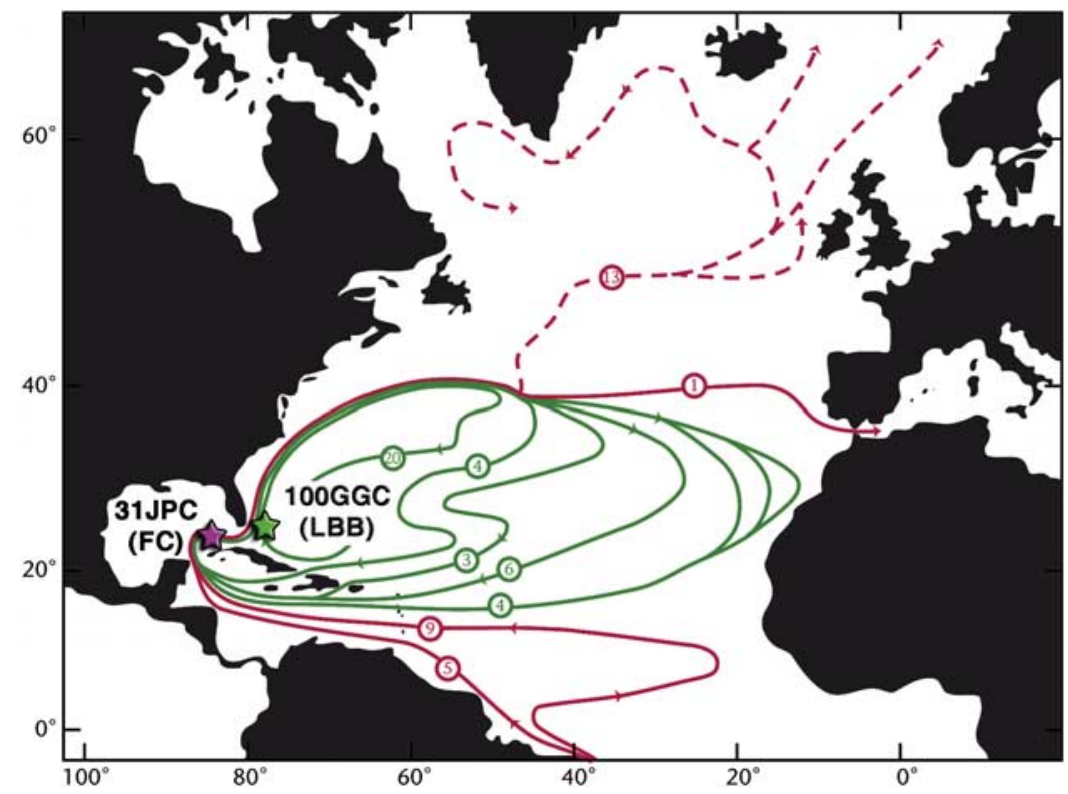

Figure 1. Map of the North Atlantic showing the locations of OCE205-2-100GGC $\left(26^{\circ} 04^{\prime} \mathrm{N}, 78^{\circ} 02^{\prime} \mathrm{W}\right.$, $1057 \mathrm{~m})$ and KNR166-2-31JPC $\left(24^{\circ} 13^{\prime} \mathrm{N}, 83^{\circ} 18^{\prime} \mathrm{W}, 751 \mathrm{~m}\right)$ and the transport estimates in Sverdrups for waters entering the Florida Current (adapted from Schmitz and McCartney [1993]). FC, Florida Current; LBB, Little Bahama Bank.

cate an increase in the influence of AAIW [Rickaby and Elderfield, 2005]. These two interpretations suggest very different roles of AAIW in the AMOC during the deglaciation. Thus, it is clear that a better understanding of the AAIW variability and how it participates in the AMOC on millennial timescales is required.

[5] In order to determine changes in intermediate-depth circulation during the past 20,000 years, we generated nutrient proxy data on two subtropical North Atlantic sediment cores. These cores lie in key locations for studying variability in the Atlantic AMOC: the Florida Current site (FC) is bathed by the northward moving waters of the AMOC surface return flow; the Little Bahama Bank site (LBB) is bathed by waters of the North Atlantic subtropical gyre. When considered together with previously published records [Boyle and Keigwin, 1987; Came et al., 2003] the new Florida Current paleonutrient record provides insights into the relative influences of northern versus southern source waters within the Florida Current during the last 20,000 years.

\section{Study Areas}

[6] Sediment core KNR166-2-31JPC $\left(24^{\circ} 13^{\prime} \mathrm{N}, 83^{\circ} 18^{\prime} \mathrm{W}\right.$, $751 \mathrm{~m}$ ) was taken from within the Florida Current, just south of the Florida Keys (Figure 1). Today, Florida Current waters contain a mixture of recirculated North Atlantic subtropical gyre waters (17 Sv) and South Atlantic waters (13 Sv) [Schmitz et al., 1993; Schmitz and Richardson, 1991]. Below $400 \mathrm{~m}$ depth, $~ 80 \%$ of the Florida Current waters are of South Atlantic origin [Schmitz and Richardson, 1991]. Sediment core OCE205-2-100GGC $\left(26^{\circ} 04^{\prime} \mathrm{N}\right.$, $\left.78^{\circ} 02^{\prime} \mathrm{W}, 1057 \mathrm{~m}\right)$ was taken from the flanks of the Little
Bahama Bank, within the Northwest Providence Channel (Figure 1), where waters flow westward from the Sargasso Sea toward the Straits of Florida [Slowey and Curry, 1995]. Waters below $1000 \mathrm{~m}$ depth are fed by the upper component of NADW, and are poorly ventilated because they originate in the subpolar gyre, where residence times are long and wind driven upwelling occurs [Jenkins, 1980; McCartney, 1982; Sarmiento et al., 1982]. Today, intermediate-depth waters at these two locations have very different nutrient concentrations: all waters originating in the North Atlantic have low initial phosphate concentrations $\left(<0.8 \mu \mathrm{mol} \mathrm{kg}{ }^{-1}\right)$, while Florida Current waters have phosphate concentrations intermediate between North Atlantic waters $\left(<0.8 \mu \mathrm{mol} \mathrm{kg}^{-1}\right)$ and AAIW (>1.4 $\left.\mu \mathrm{mol} \mathrm{kg}^{-1}\right)$ [Slowey and Curry, 1995].

\section{Methods}

[7] Thirteen accelerator mass spectrometer (AMS) radiocarbon dates were obtained for the LBB core, and ten were obtained for the FC core (Table 1). All AMS dates, including previously published dates for KNR159-536GGC [Came et al., 2003], were converted to calendar age using the calibration program, CALIB v. 5.0.2 [Stuiver and Reimer, 1993], the updated Marine04 calibration data set [Hughen et al., 2004], and a reservoir correction of 400 years. Age models are based on linear interpolation between data points. The average sedimentation rate for LBB is $\sim 6 \mathrm{~cm} / \mathrm{ka}$, with higher sedimentation rates in the more recent Holocene $(\sim 8 \mathrm{~cm} / \mathrm{ka})$ and lower rates near the last glacial $(\sim 3 \mathrm{~cm} / \mathrm{ka})$ (Figure $2 \mathrm{a})$. The average sedimentation rate for $\mathrm{FC}$ is slightly higher than $8 \mathrm{~cm} / \mathrm{ka}$ (Figure $3 \mathrm{a}$ ). Our age model for the FC core did not include the calculated calendar age for $128 \mathrm{~cm}$ owing to an apparent 
Table 1. AMS Dates and Calendar Ages ${ }^{\mathrm{a}}$

\begin{tabular}{|c|c|c|c|c|c|c|c|c|}
\hline Depth, cm & Species & NOSAMS Number & $\begin{array}{l}\text { AMS } \\
\text { Date }\end{array}$ & $\begin{array}{l}\text { AMS } \\
\text { Error }\end{array}$ & 1 or 2 Sigma & $\begin{array}{l}\text { Years Before } \\
\text { Present } \\
\text { (Lower) }\end{array}$ & $\begin{array}{l}\text { Years Before } \\
\text { Present } \\
\text { (Upper) }\end{array}$ & $\begin{array}{c}\text { Years Before } \\
\text { Present }\end{array}$ \\
\hline \multirow{4}{*}{7} & \multicolumn{7}{|c|}{ OCE205-2-100GGC } & \\
\hline & G. sacculifer & OS-181 & 1,040 & 30 & 1 & 567 & 581 & 613 \\
\hline & & & & & 1 & 594 & 648 & \\
\hline & & & & & 2 & 544 & 663 & \\
\hline \multirow[t]{2}{*}{17} & G. sacculifer & OS-27756 & 2,250 & 40 & 1 & 1,807 & 1,911 & 1,856 \\
\hline & & & & & 2 & 1,737 & 1,964 & \\
\hline \multirow[t]{2}{*}{31} & G. sacculifer & OS-27757 & 3,150 & 40 & 1 & 2,864 & 2,993 & 2,936 \\
\hline & & & & & 2 & 2,810 & 3,070 & \\
\hline \multirow[t]{2}{*}{63} & G. sacculifer & OS-27758 & 5,150 & 45 & 1 & 5,472 & 5,566 & 5,515 \\
\hline & & & & & 2 & 5,402 & 5,611 & \\
\hline \multirow[t]{2}{*}{73} & G. sacculifer & OS-27759 & 5,770 & 40 & 1 & 6,165 & 6,257 & 6,200 \\
\hline & & & & & 2 & 6,085 & 6,285 & \\
\hline \multirow[t]{2}{*}{80} & G. sacculifer & OS-27834 & 6,850 & 45 & 1 & 7,323 & 7,413 & 7,368 \\
\hline & & & & & 2 & 7,268 & 7,450 & \\
\hline \multirow[t]{2}{*}{80} & G. sacculifer & OS-180 & 6,470 & 55 & 1 & 6,884 & 7,049 & 6,970 \\
\hline & & & & & 2 & 6,824 & 7,140 & \\
\hline \multirow[t]{2}{*}{92} & G. sacculifer & OS-27835 & 8,440 & 85 & 1 & 8,959 & 9,197 & 9,059 \\
\hline & & & & & 2 & 8,775 & 9,294 & \\
\hline \multirow[t]{2}{*}{100} & G. sacculifer & OS-178 & 8,870 & 55 & 1 & 9,464 & 9,574 & 9,525 \\
\hline & & & & & 2 & 9,427 & 9,668 & \\
\hline \multirow[t]{3}{*}{109} & G. sacculifer & OS-27836 & 10,400 & 55 & 1 & 11,294 & 11,433 & 11,468 \\
\hline & & & & & 1 & 11,478 & 11,624 & \\
\hline & & & & & 2 & 11,243 & 11,707 & \\
\hline \multirow[t]{2}{*}{116} & G. sacculifer & OS-27837 & 11,750 & 110 & 1 & 13,118 & 13,303 & 13,218 \\
\hline & & & & & 2 & 13,020 & 13,415 & \\
\hline \multirow[t]{2}{*}{120} & G. sacculifer & OS-176 & 12,000 & 45 & 1 & 13,347 & 13,483 & 13,427 \\
\hline & & & & & 2 & 13,310 & 13,586 & \\
\hline \multirow[t]{2}{*}{160} & G. sacculifer & OS-174 & 23,800 & 110 & & & & 27,800 \\
\hline & & & $K N$ & $66-2-31=$ & & & & \\
\hline \multirow[t]{2}{*}{0.5} & G. sacculifer & OS-39424 & 1,640 & 40 & 1 & 1,166 & 1,254 & 1,204 \\
\hline & & & & & 2 & 1,100 & 1,283 & \\
\hline \multirow[t]{2}{*}{28} & G. sacculifer & OS-50184 & 4,380 & 45 & 1 & 4,437 & 4,582 & 4,526 \\
\hline & & & & & 2 & 4,401 & 4,690 & \\
\hline \multirow[t]{2}{*}{64} & G. sacculifer & OS-42460 & 7,310 & 50 & 1 & 7,708 & 7,831 & 7,773 \\
\hline & & & & & 2 & 7,663 & 7,899 & \\
\hline \multirow[t]{2}{*}{72} & G. sacculifer & OS-52098 & 9,110 & 50 & 1 & 10,209 & 10,296 & 10,264 \\
\hline & & & & & 2 & 10,195 & 10,407 & \\
\hline \multirow[t]{2}{*}{86} & G. sacculifer & OS-55948 & 10,400 & 55 & 1 & 11,294 & 11,433 & 11,468 \\
\hline & & & & & 2 & 11,243 & 11,707 & \\
\hline 96 & G. sacculifer & OS-50345 & 11,000 & 55 & 1 & 12,408 & 12,445 & 12,655 \\
\hline & & & & & 2 & 12,380 & 12,526 & \\
\hline 112 & G. sacculifer & OS-42461 & 12,050 & 75 & 1 & 13,401 & 13,598 & 13,500 \\
\hline & & & & & 2 & 13,322 & 13,684 & \\
\hline 128 & G. sacculifer & OS-55931 & 11,800 & 50 & 1 & 13,213 & 13,302 & 13,259 \\
\hline & & & & & 2 & 13,159 & 13,363 & \\
\hline 150 & G. sacculifer and & OS-55949 & 13,750 & 80 & 1 & 15,626 & 16,032 & 15,842 \\
\hline & G. ruber & & & & 2 & 15,440 & 16,267 & \\
\hline 160 & G. ruber & OS-42462 & 16,650 & 160 & 1 & 19,198 & 19,537 & 19,397 \\
\hline & & & & & 2 & 19,048 & 19,612 & \\
\hline & & & & & 2 & 19,656 & 19,806 & \\
\hline
\end{tabular}

${ }^{a}$ Accelerator mass spectrometer (AMS) radiocarbon dates were converted to calendar age using the online calibration program Calib 5.02 [Stuiver and Reimer, 1993], the Marine04 calibration data set [Hughen et al., 2004], and a reservoir correction of 400 years. NOSAMS is National Ocean Sciences Accelerator Mass Spectrometer Facility.

reversal at that depth. The age reversal may indicate bioturbation or, if uncertainties in the reservoir correction are considered, it may indicate an increased sedimentation rate and no bioturbation. In either case, the affected depth interval is significantly deeper in the core than the interval representing the Younger Dryas, so it does not affect our interpretation of the data.
[8] $\mathrm{Cd} / \mathrm{Ca}$ ratios were measured in the tests of the benthic foraminifer Hoeglundina elegans, which records bottom water $\mathrm{Cd}$ concentrations with a partition coefficient $\mathrm{D}_{\mathrm{P}}=$ $\left[(\mathrm{Cd} / \mathrm{Ca})_{\text {foram }} /(\mathrm{Cd} / \mathrm{Ca})_{\text {water }}\right] \approx 1.0$ [Boyle et al., 1995]. The partition coefficient for the aragonitic species $H$. elegans is constant with depth, unlike the partition coefficients of calcitic foraminifera, which are depth dependent [Boyle, 

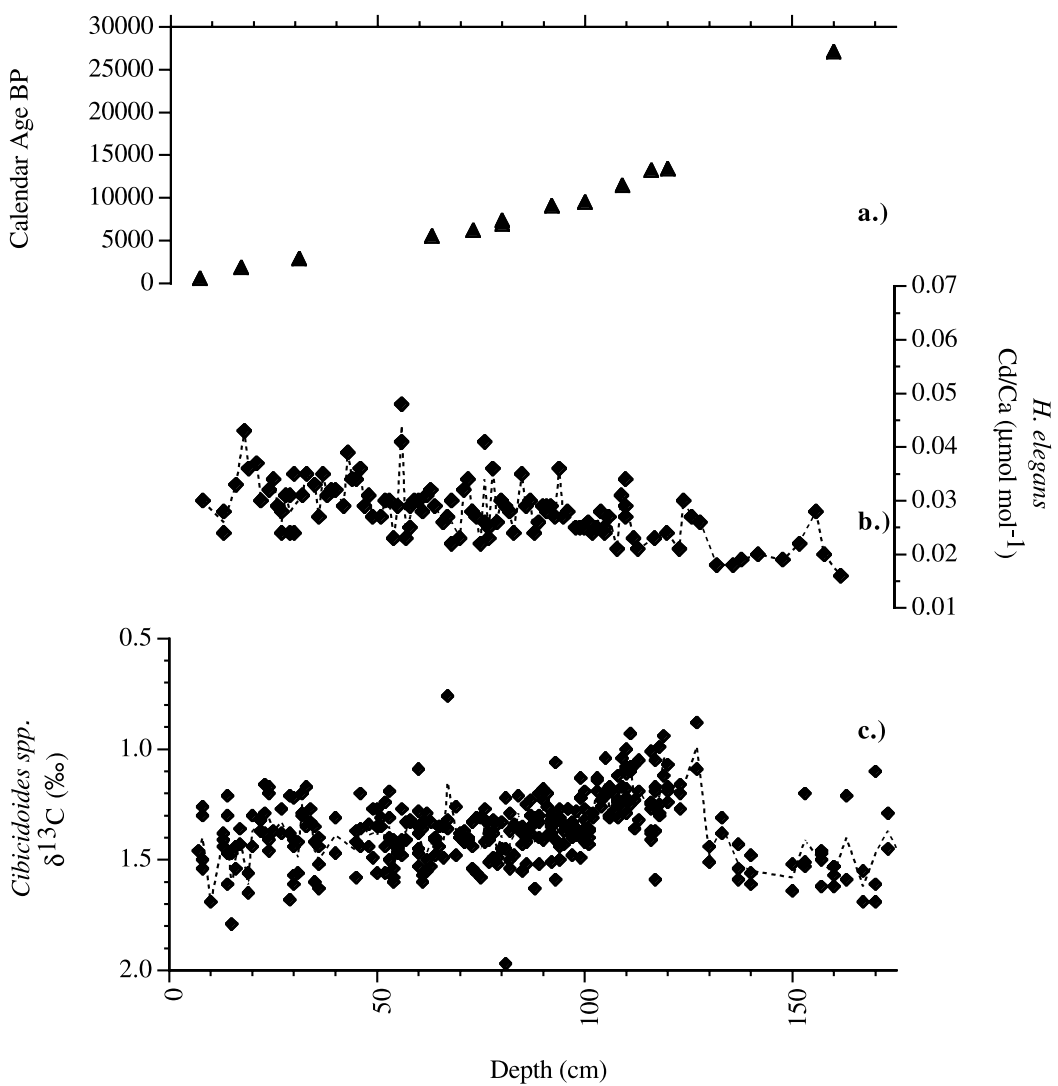

Figure 2. Benthic $\mathrm{Cd} / \mathrm{Ca}$ and $\delta^{13} \mathrm{C}$ data from OCE205-2-100GGC $\left(26.06^{\circ} \mathrm{N}, 78.03^{\circ} \mathrm{W}, 1057 \mathrm{~m}\right)$ versus depth. (a) Accelerator mass spectrometer (AMS) radiocarbon dates converted to calendar age using Calib 5.02 [Stuiver and Reimer, 1993], the Marine04 calibration data set [Hughen et al., 2004], and a reservoir correction of 400 years. (Two dates at $80 \mathrm{~cm}$ are virtually indistinguishable.) (b) All Hoeglundina elegans $\mathrm{Cd} / \mathrm{Ca}$. (c) All previously acquired Cibicidoides spp. $\delta^{13} \mathrm{C}$ [Slowey and Curry, 1995] as well as newly acquired Cibicidoides spp. (this paper).

1992]. A constant seawater Ca concentration of $0.01 \mathrm{~mol}$ $\mathrm{kg}^{-1}$ was assumed to estimate $\mathrm{Cd}$ water concentrations.

[9] Each foraminiferal sample consisted of 2-3 individual tests, which were crushed and cleaned according to the full trace metal protocol [Boyle and Keigwin, 1985] with a reversal of the oxidative and reductive steps [Boyle and Rosenthal, 1996; Rosenthal, 1994; Rosenthal et al., 1995]. Samples were dissolved in trace metal clean $\mathrm{HNO}_{3}$ to obtain solutions of approximately $200 \mathrm{ppm} \mathrm{Ca}$. Ratios were measured using a Thermo-Finnigan Element2 sector field single collector ICP-MS following the method of Rosenthal et al. [Rosenthal et al., 1999], with the addition of a $\mathrm{Ca}$ matrix correction. $\mathrm{Mn} / \mathrm{Ca}$ was also measured in order to monitor contamination due to manganese carbonate overgrowths, which are a potential source of contamination in many species of benthic foraminifera [Boyle, 1983]. However, the species $H$. elegans was chosen for this study because it does not experience the contamination caused by such overgrowths [Boyle et al., 1995].

[10] Converting ICP-MS intensity ratios to elemental ratios using an external standard requires similar $[\mathrm{Ca}]$ in both the sample and the standard owing to a calcium matrix effect. To correct for samples with varying $[\mathrm{Ca}]$, we ran a series of standards with identical element to $\mathrm{Ca}$ ratios, but with $\mathrm{Ca}$ concentrations that varied over the anticipated sample concentration range. The resulting matrix effect was calculated and the sample ratios were corrected. The corrections were less than $\pm 0.012 \mu \mathrm{mol} \mathrm{mol}^{-1} \mathrm{Cd} / \mathrm{Ca}$.

[11] In order to assess the precision of measurements on the ICP-MS, three consistency standards were treated as samples in each of the runs in which the data were generated. Mean $\mathrm{Cd} / \mathrm{Ca}$ values for the three consistency standards were $0.127 \mu \mathrm{mol} \mathrm{mol}^{-1}, 0.044 \mu \mathrm{mol} \mathrm{mol}^{-1}$, and $0.083 \mu \mathrm{mol} \mathrm{mol}{ }^{-1}$. Relative standard deviations were $\pm 0.6 \%(\mathrm{n}=5), \pm 3.7 \%(\mathrm{n}=3)$, and $\pm 1.3 \%(\mathrm{n}=4)$, respectively. For $H$. elegans, which has a partition coefficient of 1 , the resulting $\mathrm{Cd}_{\mathrm{W}}$ error is $\pm 0.016 \mathrm{nmol} \mathrm{kg}^{-1}$. Replicate analyses were performed where sample sizes permitted. All replicate data are presented in Figures 2 and 3.

[12] Samples used for carbon isotopic analyses consisted of 1-4 individual tests of the benthic foraminiferal species Cibicidoides spp. Carbon isotopic data for core OCE205-2100GGC were generated using a Finnigan-MAT 252 with Kiel II carbonate preparation device at the Woods Hole Oceanographic Institution (WHOI). Carbon isotopic data for core KNR166-2-31JPC were generated using both a GV Optima with Multiprep at the Lamont-Doherty Earth Ob- 

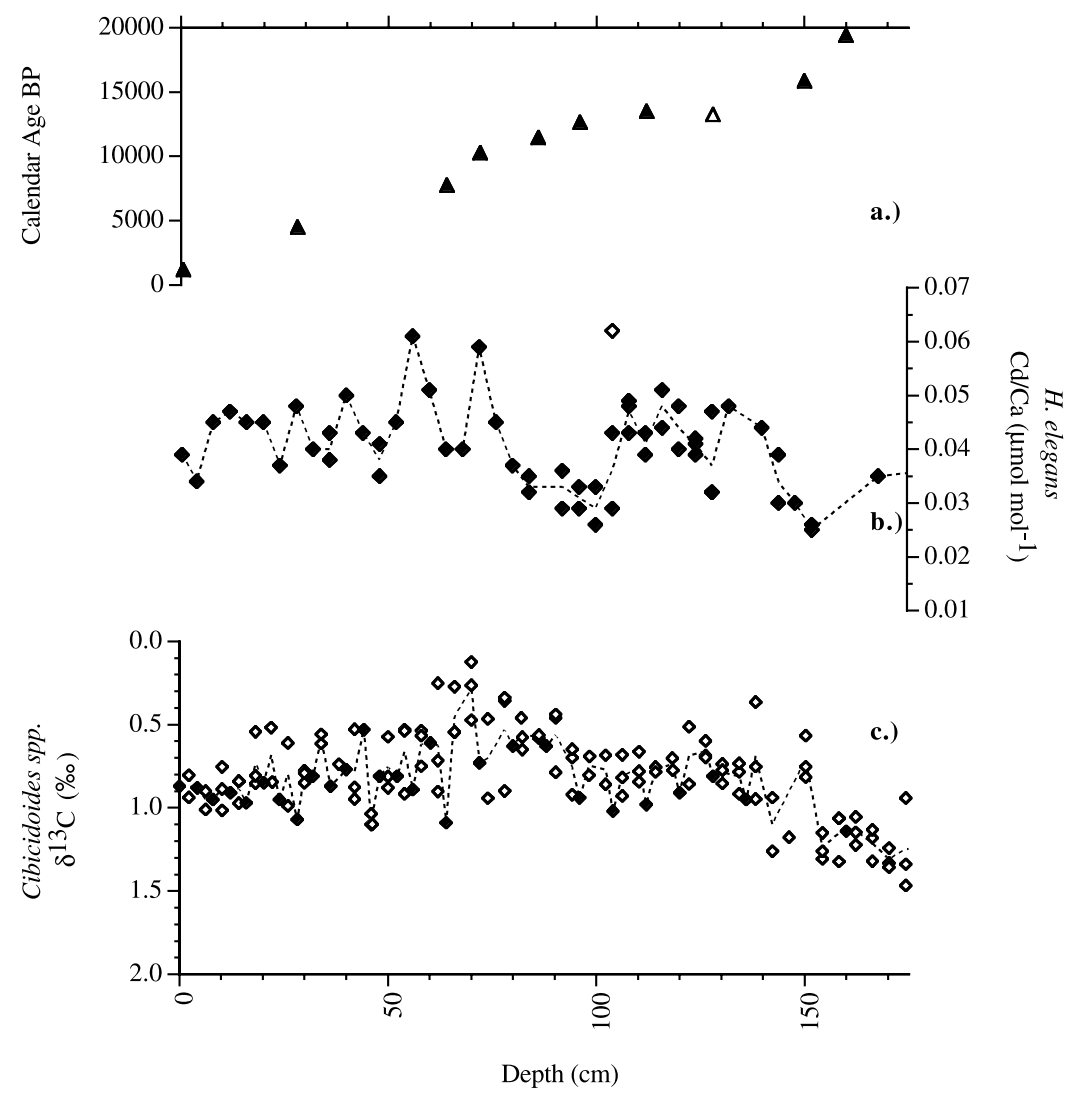

Figure 3. Benthic $\mathrm{Cd} / \mathrm{Ca}$ and $\delta^{13} \mathrm{C}$ data from KNR166-2-31JPC $\left(24.22^{\circ} \mathrm{N}, 83.30^{\circ} \mathrm{W}, 751 \mathrm{~m}\right)$ versus depth. (a) AMS radiocarbon dates converted to calendar age using Calib 5.02 [Stuiver and Reimer, 1993], the Marine04 calibration data set [Hughen et al., 2004], and a reservoir correction of 400 years; open symbol was excluded from the age model. (b) All $H$. elegans $\mathrm{Cd} / \mathrm{Ca}$; open symbol was excluded from the average. (c) All Cibicidoides spp. $\delta^{13} \mathrm{C}$; open symbols represent analyses of individual foraminifers, and closed symbols represent analyses of multiple individuals.

servatory, and a Finnigan-MAT 253 with Kiel III carbonate preparation device at WHOI. Analytical precision for carbon isotopic analyses is $\pm 0.04 \%$ o $(1 \sigma)$.

\section{Results and Discussion}

\subsection{Florida Current $\mathbf{C d}_{\mathrm{w}}$}

[13] The $\mathrm{Cd}_{\mathrm{W}}$ results from the $\mathrm{FC}$ site reveal a glacialinterglacial trend of increasing $\mathrm{Cd}_{\mathrm{W}}$ (Figure 4). Minimum $\mathrm{Cd}_{\mathrm{W}}\left(0.25 \mathrm{nmol} \mathrm{kg}^{-1}\right)$ was achieved at $\sim 16.5 \mathrm{ka}$, although a data gap between $22 \mathrm{ka}$ and $16.5 \mathrm{ka}$ allow for lower values during that time. Nevertheless, low values at $16.5 \mathrm{ka}$ indicate a reduced influence of nutrient-rich waters at this site relative to today, perhaps associated with the weak AMOC documented for the Heinrich 1 (H1) iceberg discharge event [McManus et al., 2004]. Higher $\mathrm{Cd}_{\mathrm{W}}$ values $\left(0.44 \mathrm{nmol} \mathrm{kg}{ }^{-1}\right)$ were achieved at $\sim 15.2 \mathrm{ka}$, and persisted through the Bølling-Allerød warm period. At $\sim 12.8 \mathrm{ka}$, the sharp depletion in the $\delta^{18} \mathrm{O}$ of Greenland ice marks the abrupt northern hemisphere cooling of the Younger Dryas. Approximately coincident with the North Atlantic cooling, at $\sim 13 \mathrm{ka}$, the $\mathrm{Cd}_{\mathrm{W}}$ at the $\mathrm{FC}$ site decreased rapidly, culminating in values of $0.29 \mathrm{nmol} \mathrm{kg}^{-1}$ during the Younger Dryas, similar to glacial values. At $\sim 11.5 \mathrm{ka}$, the GISP2 $\delta^{18} \mathrm{O}$ record exhibits a rapid warming in the high northern latitudes, marking the end of the Younger Dryas cold period. At the $\mathrm{FC}$ site, however, $\mathrm{Cd}_{\mathrm{W}}$ remained low until $\sim 11 \mathrm{ka}$. After $\sim 11 \mathrm{ka}, \mathrm{Cd}_{\mathrm{W}}$ increased, indicating a Holocene water mass with the renewed contribution of nutrientrich waters.

[14] Comparison of the FC results with intermediatedepth records from the Brazil Margin $\left(27^{\circ} 31^{\prime} \mathrm{S}, 46^{\circ} 28^{\prime} \mathrm{W}\right.$, $1268 \mathrm{~m} ; \mathrm{BM}$ ) in the western South Atlantic [Came et al., 2003] and from LBB suggests that $\mathrm{Cd}_{\mathrm{W}}$ variability within the Florida Current reflects changes in the relative contribution of southern and northern source waters (Figure 4b). As stated above, the FC site is influenced both by intermediate-depth southern source waters and by recirculated North Atlantic subtropical gyre waters, making it a suitable location to monitor the relative influences of the two endmember sources. At $16.5 \mathrm{ka}, \mathrm{FC} \mathrm{Cd}_{\mathrm{W}}$ was similar to that of the intermediate-depth North Atlantic, indicating a strong influence of North Atlantic Intermediate Water. After $16.5 \mathrm{ka}$, coincident with the early gradual warming in the high-latitude North Atlantic, $\mathrm{FC} \mathrm{Cd}_{\mathrm{W}}$ values began to increase toward South Atlantic values, indicating an increasing influence of intermediate-depth southern source waters during deglaciation. $\mathrm{Cd}_{\mathrm{W}}$ values remained close to 


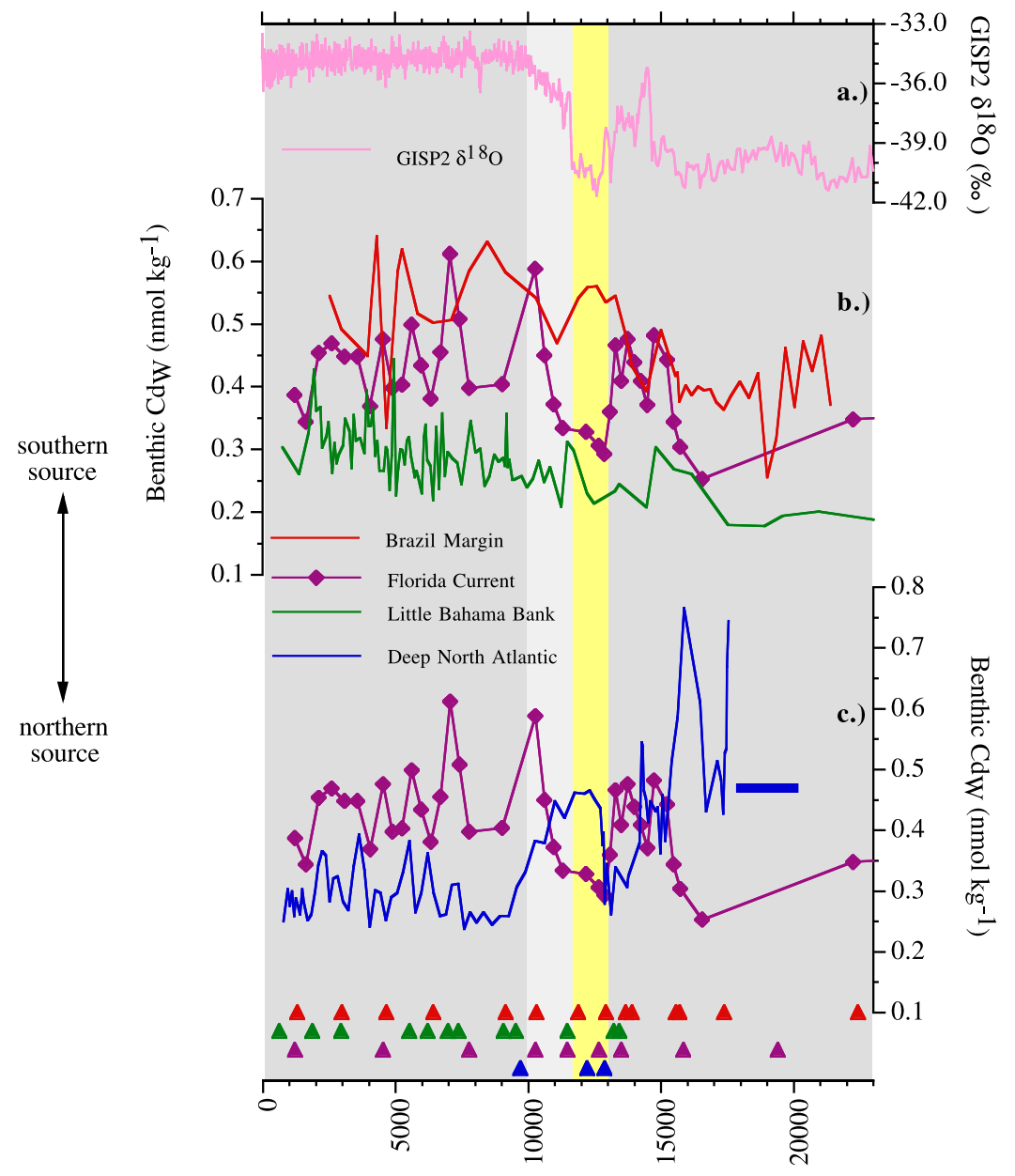

Age (yrs BP)

Figure 4. Benthic $\mathrm{Cd}_{\mathrm{W}}$ versus calendar age. (a) Greenland Ice Sheet Project (GISP2) $\delta^{18} \mathrm{O}$ [Grootes et al., 1993]. (b) Average $\mathrm{Cd}_{\mathrm{W}}$ from KNR166-2-31JPC $\left(24^{\circ} 13^{\prime} \mathrm{N}, 83^{\circ} 18^{\prime} \mathrm{W}, 751 \mathrm{~m}\right.$; purple), OCE205-2$100 \mathrm{GGC}\left(26^{\circ} 04^{\prime} \mathrm{N}, 78^{\circ} 02^{\prime} \mathrm{W}, 1057 \mathrm{~m}\right.$; green), and KNR159-5-36GGC $\left(27^{\circ} 31^{\prime} \mathrm{S}, 46^{\circ} 28^{\prime} \mathrm{W}, 1268 \mathrm{~m}\right.$; red) [Came et al., 2003]. (c) Average $\mathrm{Cd}_{\mathrm{W}}$ from KNR166-2-31JPC (purple) and EN120-GGC1 $\left(33^{\circ} 40^{\prime} \mathrm{N}\right.$, $57^{\circ} 37^{\prime} \mathrm{W}, 4450 \mathrm{~m}$; blue) [Boyle and Keigwin, 1987]. The glacial $\mathrm{Cd}_{\mathrm{W}}$ estimate for the deep North Atlantic (blue bar) is based on data from IOS82 PC SO1 $\left(42^{\circ} 23^{\prime} \mathrm{N}, 23^{\circ} 31^{\prime} \mathrm{W}, 3540 \mathrm{~m}\right)$ [Boyle, 1992]. The age models for $31 \mathrm{JPC}, 100 \mathrm{GGC}$, and $36 \mathrm{GGC}$ are based on AMS radiocarbon dates converted to calendar age (purple triangles for 31JPC, green triangles for $100 \mathrm{GGC}$, and red triangles for 36GGC) and linear interpolation between points. The age model for GGC1 is based on cross correlation with features that were radiocarbon dated in nearby cores [Boyle and Keigwin, 1987]. Three AMS radiocarbon dates for GGC1 (blue triangles) [Came et al., 2003] support the model of Boyle and Keigwin [1987]. Yellow shading marks the Younger Dryas interval.

those of the South Atlantic for all of the Bølling-Allerød.

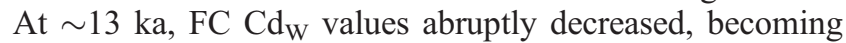
once more like those of the North Atlantic subtropical gyre. The nearly identical values of $0.29 \mathrm{nmol} \mathrm{kg}^{-1}$ at both FC and LBB at $\sim 11.5$ ka suggest that waters of the Florida Current may have had little or no southern source component during the Younger Dryas. At $\sim 10 \mathrm{ka}, \mathrm{Cd}_{\mathrm{W}}$ at the FC site became more like the South Atlantic again, and varied between the two end-member concentrations for the remainder of the record.

[15] Comparison of the intermediate-depth results with results from the deep North Atlantic (EN120-GGC1; $\left.33^{\circ} 40^{\prime} \mathrm{N}, 57^{\circ} 37^{\prime} \mathrm{W}, 4450 \mathrm{~m}\right)$ [Boyle and Keigwin, 1987] (Figure 4c) suggests that the interplay between AAIW and NAIW is related to the role of AAIW as a supplier of NADW. Prior to $\sim 15.5 \mathrm{ka}$, all three intermediate-depth sites (FC, LBB, and BM) had lower $\mathrm{Cd}_{\mathrm{W}}$ than the deep North Atlantic, consistent with a decreased influence of NADW and the formation of GNAIW [Boyle and Keigwin, 1987; Curry and Oppo, 2005], which affected all three intermediate-depth locations during the last glacial. However, higher nutrients at FC than LBB suggests that a contribution of southern source waters reached the FC site, consistent with continued overturning in the North Atlantic [McManus 


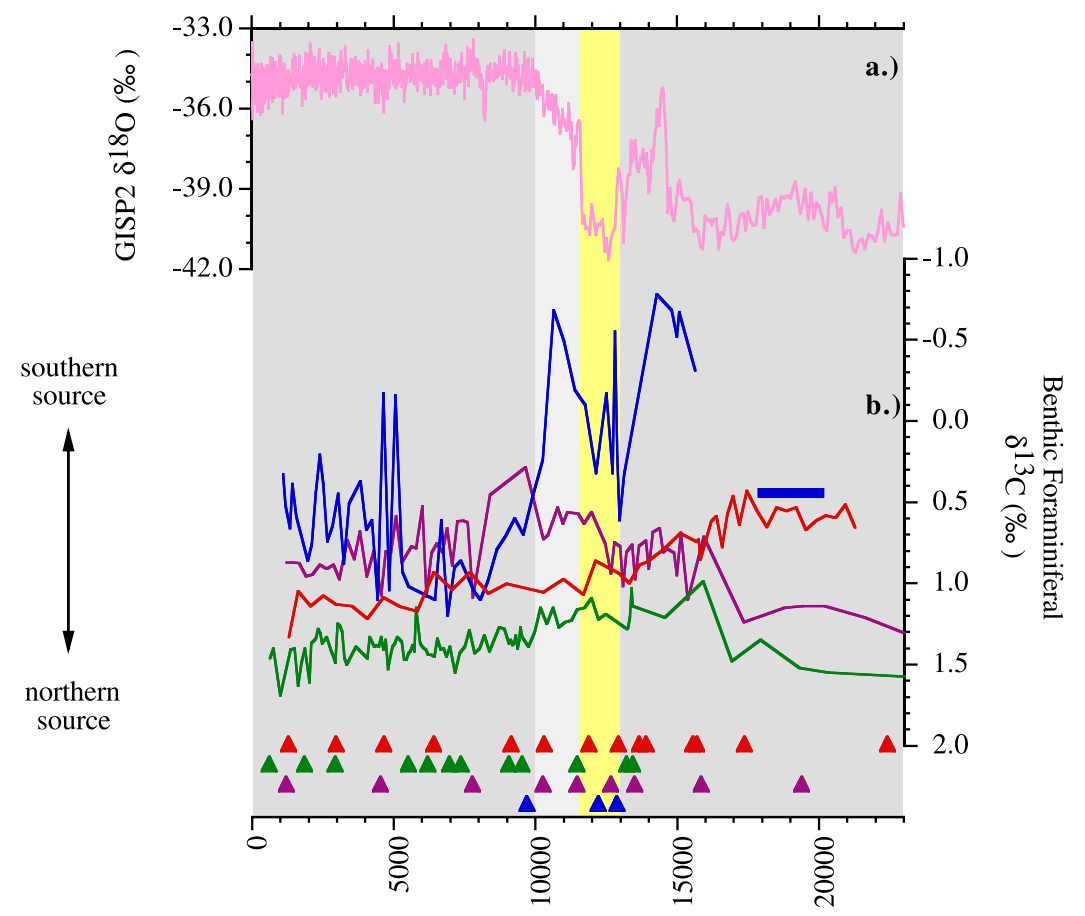

Age (yrs BP)

Figure 5. Benthic $\delta^{13} \mathrm{C}$ versus calendar age. (a) GISP2 $\delta^{18} \mathrm{O}$ [Grootes et al., 1993]. (b) Average $\delta^{13} \mathrm{C}$ from KNR166-2-31JPC $\left(24.22^{\circ} \mathrm{N}, 83.30^{\circ} \mathrm{W}, 751 \mathrm{~m}\right.$; purple), OCE205-2-100GGC $\left(26.06^{\circ} \mathrm{N}, 78.03^{\circ} \mathrm{W}\right.$, $1057 \mathrm{~m}$; green) [Slowey and Curry, 1995], KNR159-5-36GGC $\left(27^{\circ} 31^{\prime} \mathrm{S}, 46^{\circ} 28^{\prime} \mathrm{W}, 1268 \mathrm{~m}\right.$; red) [Oppo and Horowitz, 2000], and EN120-GGC1 $\left(33^{\circ} 40^{\prime} \mathrm{N}, 57^{\circ} 37^{\prime} \mathrm{W}, 4450 \mathrm{~m}\right.$; blue) [Boyle and Keigwin, 1987]. The glacial $\delta^{13} \mathrm{C}$ estimate for the deep North Atlantic (blue bar) is based on data from IOS82 PC SO1 $\left(42^{\circ} 23^{\prime} \mathrm{N}, 23^{\circ} 31^{\prime} \mathrm{W}, 3540 \mathrm{~m}\right)$ [Boyle, 1992]. Triangles are AMS dates converted to calendar age. Yellow shading marks the Younger Dryas interval.

et al., 2004]. At $\sim 14 \mathrm{ka}$, the deep North Atlantic became more nutrient-depleted than both the intermediate-depth South Atlantic and the Florida Current, consistent with renewed production of NADW [Boyle and Keigwin, 1987] and an increase in overturning during the Bølling-Allerød warm period [McManus et al., 2004]. The interglacial subsurface geometry was interrupted from $\sim 13$ to $11 \mathrm{ka}$, when the deep North Atlantic was once again more nutrientrich than the waters of the Florida Current indicating reduced NADW and reduced northward penetration of AAIW. At $\sim 9$ ka the modern geometry and water mass nutrient concentrations were established: the North Atlantic deep and intermediate sites were all nutrient-depleted, the intermediate-depth South Atlantic was nutrient-rich, and the Florida Current waters were intermediate in nutrient concentration between the South Atlantic and the North Atlantic intermediate-depth sites.

[16] Taken together, the $\mathrm{Cd}_{\mathrm{W}}$ results from the deep and intermediate-depth Atlantic suggest that an abrupt decrease in the northward penetration of intermediate-depth southern source waters (including AAIW) occurred concurrently with the onset of the Younger Dryas cooling in the North Atlantic and the associated reduction in the influence of NADW. The reduced influence of both AAIW and NADW in the North Atlantic persisted through the Younger Dryas and continued for an additional $\sim 2000$ years after the end of the cold event over Greenland (Figure 4c).

\subsection{Florida Current $\delta^{13} \mathrm{C}$}

[17] The $\delta^{13} \mathrm{C}$ results from FC, LBB [Slowey and Curry, 1995], the Brazil Margin [Oppo and Horowitz, 2000], and the deep North Atlantic [Boyle and Keigwin, 1987] record glacial-interglacial circulation changes that are similar to those implied by the $\mathrm{Cd}_{\mathrm{W}}$ results (Figure 5). During the last glacial, the $\delta^{13} \mathrm{C}$ results indicate that nutrient concentrations at the FC site were intermediate between the North Atlantic and South Atlantic intermediate-depth sites, and more nutrient-depleted relative to the deep North Atlantic, consistent with the $\mathrm{Cd}_{\mathrm{W}}$ results. Overall, the $\delta^{13} \mathrm{C}$ results from FC suggest a glacial-interglacial trend of increasing nutrients, again, consistent with the $\mathrm{Cd}_{\mathrm{W}}$ results. However, during the Holocene, the Brazil Margin $\delta^{13} \mathrm{C}$ values were higher than those at the FC site. As discussed by Came et al. [2003], this is owing to the increasing influence of a high $\delta^{13} \mathrm{C}_{\mathrm{AS}}$ water mass at the Brazil Margin site.

\subsection{Younger Dryas Circulation Modes}

[18] Our interpretation of the Younger Dryas $\mathrm{Cd}_{\mathrm{W}}$ results, that the northward penetration of southern source intermediate-depth water decreased during this period of reduced AMOC, does not agree with the interpretation presented for 


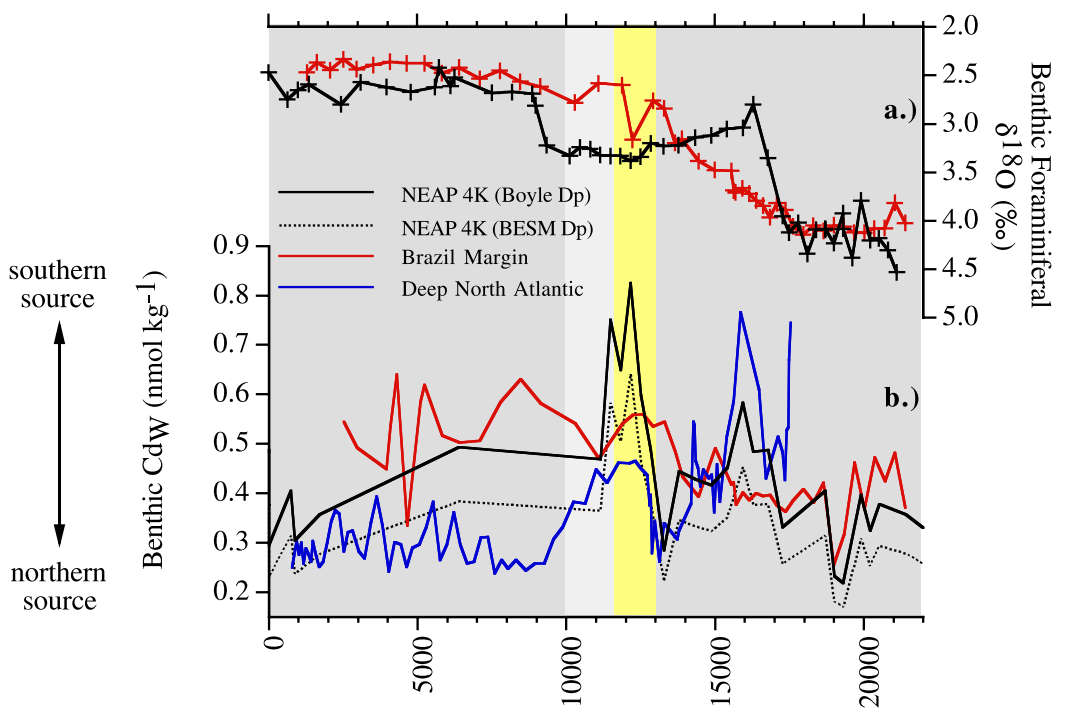

Age (yrs BP)

Figure 6. Comparison with NEAP $4 \mathrm{~K}$. (a) Benthic foraminiferal $\delta^{18} \mathrm{O}$ from KNR159-5-36GGC (red) [Oppo and Horowitz, 2000] and NEAP $4 \mathrm{~K}\left(61^{\circ} 30^{\prime} \mathrm{N}, 24^{\circ} 10^{\prime} \mathrm{W}, 1627 \mathrm{~m}\right.$; black) [Rickaby and Elderfield, 2005]. (b) $\mathrm{Cd}_{\mathrm{W}}$ from EN120-GGC1 (blue) [Boyle and Keigwin, 1987], KNR159-5-36GGC (red) [Came et al., 2003], and NEAP 4K (black) [Rickaby and Elderfield, 2005]. Dashed line is $\mathrm{Cd}_{\mathrm{W}}$ values calculated using the $\mathrm{D}_{\mathrm{P}}$ of Bertram et al. [1995] (BESM); solid line is $\mathrm{Cd}_{\mathrm{W}}$ values calculated using the $\mathrm{D}_{\mathrm{P}}$ of Boyle [1992]. Yellow shading marks the Younger Dryas interval.

the $\mathrm{Cd}_{\mathrm{W}}$ record from intermediate-depth, high-latitude North Atlantic core NEAP $4 \mathrm{~K}\left(61^{\circ} 30^{\prime} \mathrm{N}, 24^{\circ} 10^{\prime} \mathrm{W}, 1627 \mathrm{~m}\right)$ [Rickaby and Elderfield, 2005]. The authors argue that high $\mathrm{Cd}_{\mathrm{W}}$ values at intermediate depths in both the South Atlantic (Brazil Margin; $1268 \mathrm{~m}$ ) and the North Atlantic (NEAP 4K; $1627 \mathrm{~m}$ ) mark the presence of AAIW at both locations during the Younger Dryas and Heinrich Event 1 (Figure 6b).

[19] It has been hypothesized that the northward penetration of AAIW might intensify during an event such as the Younger Dryas or $\mathrm{H} 1$ if a large freshwater flux to the surface of the Atlantic were to cause an ocean "off" mode, in which the density of AAIW was greater than the density of NADW [Keeling and Stephens, 2001]:

$$
\rho_{\mathrm{AAIW}}>\rho_{\mathrm{NADW}} \cdot
$$

The resulting ocean circulation would include a complete cessation of NADW formation and a compensating southward outflow of saline thermocline water [Weaver et al., 2003]. Rickaby and Elderfield [2005] propose this configuration, with AAIW reaching the high-latitude North Atlantic, to explain high $\mathrm{Cd}_{\mathrm{W}}$ for the Younger Dryas and H1. Our data, which demonstrate a close correspondence between times of reduced AMOC and reduced northward penetration of AAIW, argue against this hypothesis.

[20] Furthermore, since $\delta^{18} \mathrm{O}$ of calcite is conservative within a water mass, benthic $\delta^{18} \mathrm{O}$ values at NEAP $4 \mathrm{~K}$, which were as much as $0.8 \%$ o higher than at the Brazil Margin site, suggest that it is unlikely that the two sites were bathed by the same water mass during the Younger Dryas
(Figure 6a). Similarly, benthic $\delta^{18} \mathrm{O}$ values at NEAP 4K, which were as much as $1.0 \%$ o lower than at the Brazil Margin site, suggest that this hypothesis is unlikely for $\mathrm{H} 1$.

[21] Alternative explanations for the high $\mathrm{Cd}_{\mathrm{W}}$ at the NEAP 4K site during the Younger Dryas and H1 include sample contamination or reduced ventilation and enhanced organic matter remineralization. NEAP $4 \mathrm{~K}$ is located on the Björn Drift in the high-latitude North Atlantic, and is bathed by Iceland-Faeroe Ridge overflow waters, which sink to great depths and contribute to NADW. If a decrease in highlatitude convective activity occurred during the Younger Dryas, and overflows were reduced, the NEAP 4K site may have been less ventilated and more nutrient-enriched. Therefore, it is possible to account for the nutrient enrichment in the high-latitude North Atlantic without invoking an "off" circulation mode, which requires a complete cessation of NADW production and a southward surface return flow. The alternative explanation involving reduced ventilation and organic matter remineralization is consistent with the observed nutrient distributions. Furthermore, we note that organic matter remineralization or "aging" of southern source waters is not a suitable explanation for the reduced nutrient content at the FC site during the Younger Dryas, because remineralization can only cause an increase in the nutrient content of a water mass.

\section{Conclusion}

[22] The new $\mathrm{Cd}_{\mathrm{W}}$ results from $\mathrm{FC}$ core KNR166-231JPC document a significant reduction in the influence of southern versus northern source water within the Florida Current during the Younger Dryas and until $\sim 11 \mathrm{ka}$. Today, 
intermediate-depth southern source waters are a significant component of the northward return flow of the overturning circulation. A reduction of their influence at the FC site during the Younger Dryas suggests a significant reduction in the deep overturning circulation, consistent with previous studies [Boyle and Keigwin, 1987; McManus et al., 2004; Stanford et al., 2006]. A shallow overturning of North Atlantic waters [Marchitto et al., 1998], with NAIW reaching the $\mathrm{FC}$, is consistent with these new results. The low-nutrient event at the FC site and the accompanying high-nutrient event in the deep North Atlantic site [Boyle and Keigwin, 1987] were 2000 years longer than the Younger Dryas cooling over Greenland. During these 2000 years of continued strengthening of NADW and its shallow return flow, climate amelioration also continued. The end of gradual warming over Greenland at $10 \mathrm{ka}$ approximately coincides with the time that the deep North Atlantic became irreversibly more nutrient depleted than the FC site, providing additional confirmation of a close link between NADW, AAIW, and North Atlantic climate.

[23] Acknowledgments. We thank Y. Rosenthal, U. Ninnemann, and an anonymous reviewer for insightful comments. We also thank S. Thorrold, D. Ostermann, S. Birdwhistell, L. Baker, and H. Griffiths for their assistance in the laboratory. This work was funded by the NSF and the WHOI Ocean and Climate Change Institute. The cores used in this study are archived at the WHOI core repository, which is supported by the NSF.

\section{References}

Bertram, C. J., H. Elderfield, N. J. Shackleton, and J. A. MacDonald (1995), Cadmium/calcium and carbon isotope reconstructions of the glacial northeast Atlantic Ocean, Paleoceanography, 10, 563-578.

Boyle, E. A. (1983), Manganese carbonate overgrowths on foraminifera tests, Geochim. Cosmochim. Acta, 47, 1815-1819.

Boyle, E. A. (1988), Cadmium: Chemical tracer of deep water paleoceanography, Paleoceanography, 3, 471-489.

Boyle, E. A. (1992), Cadmium and $\delta^{13} \mathrm{C}$ paleochemical ocean distributions during the stage 2 glacial maximum, Annu. Rev. Earth Planet. Sci., 20, 245-287.

Boyle, E. A., and L. D. Keigwin (1982), Deep circulation of the North Atlantic over the last 200,000 years: Geochemical evidence, Science, 218, 784-787.

Boyle, E. A., and L. D. Keigwin (1985), Comparison of Atlantic and Pacific paleochemical records for the last 215,000 years: Changes in deep ocean circulation and chemical inventories, Earth Planet. Sci. Lett., 76, 135-150.

Boyle, E. A., and L. D. Keigwin (1987), North Atlantic thermohaline circulation during the past 20,000 years linked to high-latitude surface temperature, Nature, 330, 35-40.

Boyle, E. A., and Y. Rosenthal (1996), Chemical hydrography of the South Atlantic during the Last Glacial Maximum: $\mathrm{Cd}$ and $\delta^{13} \mathrm{C}$, in The South Atlantic: Present and Past Circulation, edited by G. Wefer, pp. 423-443, SpringerVerlag, Berlin.

Boyle, E. A., L. D. Labeyrie, and J.-C. Duplessy (1995), Calcitic foraminiferal data confirmed by cadmium in aragonitic Hoeglundina: Application to the Last Glacial Maximum in the northern Indian Ocean, Paleoceanography, 10, 881-900.

Broecker, W. S., D. M. Peteet, and D. Rind (1985), Does the ocean-atmosphere system have more than one stable mode of operation?, Nature, 315, 21-25.

Came, R. E., D. W. Oppo, and W. B. Curry (2003), Atlantic Ocean circulation during the Younger Dryas: Insights from a new $\mathrm{Cd} / \mathrm{Ca}$ record from the western subtropical South Atlantic, Paleoceanography, 18(4), 1086, doi:10.1029/2003PA000888.

Curry, W. B., and G. P. Lohmann (1982), Carbon isotopic changes in benthic foraminifera from the western South Atlantic: Reconstruction of glacial abyssal circulation patterns, Quat. Res., $18,218-235$.
Curry, W. B., and D. W. Oppo (2005), Glacial water mass geometry and the distribution of $\delta^{13} \mathrm{C}$ of $\sum \mathrm{CO}_{2}$ in the western Atlantic Ocean, Paleoceanography, 20, PA1017, doi:10.1029/ 2004PA001021.

Curry, W. B., J.-C. Duplessy, L. D. Labeyrie, and N. J. Shackleton (1988), Changes in the distribution of $\delta^{13} \mathrm{C}$ of deep water $\sum \mathrm{CO}_{2}$ between the last glaciation and the Holocene, Paleoceanography, 3, 317-341.

Duplessy, J.-C., N. J. Shackleton, R. G. Fairbanks, L. D. Labeyrie, D. W. Oppo, and N. Kallel (1988), Deep water source variations during the last climatic cycle and their impact on the global deep water circulation, Paleoceanography, 3, 343-360.

Grootes, P. M., M. Stuiver, J. W. C. White, S. J. Johnsen, and J. Jouzel (1993), Comparison of oxygen-isotope records from the GISP2 and GRIP Greenland ice cores, Nature, 366, $552-554$.

Hester, K., and E. A. Boyle (1982), Water chemistry control of cadmium content in recent benthic foraminifera, Nature, 298, 260-262.

Hughen, K. A., et al. (2004), Marine04 marine radiocarbon age calibration, $0-26$ cal kyr BP, Radiocarbon, 46, 1059-1086.

Jenkins, W. J. (1980), Tritium and He-3 in the Sargasso Sea, J. Mar. Res., 38, 533-569.

Keeling, R. F., and B. B. Stephens (2001), Antarctic sea ice and the control of Pleistocene climate instability, Paleoceanography, 16, $112-131$.

Kroopnick, P. M. (1985), The distribution of $\delta^{13} \mathrm{C}$ of $\sum \mathrm{CO}_{2}$ in the world oceans, Deep Sea Res., Part A, 32, 57-84.

Lynch-Stieglitz, J., W. B. Curry, and N. C. Slowey (1999), Weaker Gulf Stream in the Florida straits during the last glacial maximum, Nature, 402, 644-648

Marchitto, T. M., W. B. Curry, and D. W. Oppo (1998), Millennial-scale changes in North Atlantic circulation since the last glaciation, Nature, 393, 557-561.

Marchitto, T. M., D. W. Oppo, and W. B. Curry (2002), Paired benthic foraminiferal $\mathrm{Cd} / \mathrm{Ca}$ and $\mathrm{Zn} / \mathrm{Ca}$ evidence for a greatly increased presence of Southern Ocean Water in the glacial North Atlantic, Paleoceanography, 17(3), 1038, doi:10.1029/2000PA000598.

McCartney, M. S. (1982), The subtropical recirculation of mode waters, J. Mar. Res., 40, suppl., 427-464.

McManus, J. F., R. Francois, J. M. Gherardi, L. D. Keigwin, and S. Brown-Leger (2004),
Collapse and rapid resumption of Atlantic meridional circulation linked to deglacial climate changes, Nature, 428, 834-837.

Oppo, D. W., and M. Horowitz (2000), Glacial deep water geometry: South Atlantic benthic foraminiferal $\mathrm{Cd} / \mathrm{Ca}$ and $\delta^{13} \mathrm{C}$ evidence, Paleoceanography, 15, 147-160.

Oppo, D. W., and S. J. Lehman (1993), Middepth circulation of the subpolar North Atlantic during the Last Glacial Maximum, Science, 259, 1148-1152.

Rickaby, R. E. M., and H. Elderfield (2005), Evidence from the high-latitude North Atlantic for variations in Antarctic Intermediate water flow during the last deglaciation, Geochem. Geophys. Geosyst., 6, Q05001, doi:10.1029/ 2004GC000858.

Rosenthal, Y. (1994), Late quaternary paleochemistry of the Southern Ocean: Evidence from cadmium variability in sediments and foraminifera, Ph.D thesis, 186 pp., Woods Hole Oceanogr. Inst., Woods Hole, Mass.

Rosenthal, Y., P. Lam, E. A. Boyle, and J. Thomson (1995), Authigenic cadmium enrichments in suboxic sediments: Precipitation and postdepositional mobility, Earth Planet. Sci. Lett., 132, 99-111.

Rosenthal, Y., M. P. Field, and R. M. Sherrell (1999), Precise determination of element/calcium ratios in calcareous samples using sector field inductively coupled plasma mass spectrometry, Anal. Chem., 71, 3248-3253.

Sarmiento, J. L., C. G. Rooth, and W. Roether (1982), The North Atlantic tritium distribution in 1972, J. Geophys. Res., 87, 8047-8056.

Schmitz, W. J., and M. S. McCartney (1993), On the North Atlantic circulation, Rev. Geophys., 31, 29-49.

Schmitz, W. J., and P. L. Richardson (1991), On the sources of the Florida Current, Deep Sea Res., Part A, 38, S379-S409.

Schmitz, W. J., J. R. Luyten, and R. W. Schmitt (1993), On the Florida Current T/S envelope, Bull. Mar. Sci., 53, 1048-1065.

Slowey, N. C., and W. B. Curry (1995), Glacial-interglacial differences in circulation and carbon cycling within the upper western NorthAtlantic, Paleoceanography, 10, 715-732.

Stanford, J. D., E. J. Rohling, S. E. Hunter, A. P. Roberts, S. O. Rasmussen, E. Bard, J. F. McManus, and R. G. Fairbanks (2006), Timing of meltwater pulse $1 \mathrm{a}$ and climate responses to meltwater injections, Paleoceanography, 21, PA4103, doi:10.1029/2006PA001340. 
Stuiver, M., and P. J. Reimer (1993), Extended ${ }^{14} \mathrm{C}$ database and revised CALIB radiocarbon calibration program, Radiocarbon, 35, 215230.

Weaver, A. J., O. A. Saenko, P. U. Clark, and J. Mitrovica (2003), Meltwater pulse 1A from Antarctica as a trigger of the Bølling-Allerød warm interval, Science, 299, 1709-1713.

Zahn, R., and A. Stüber (2002), Suborbital intermediate water variability inferred from paired benthic foraminiferal $\mathrm{Cd} / \mathrm{Ca}$ and $\delta^{13} \mathrm{C}$ in the tropical West Atlantic and linking with North Atlantic climates, Earth Planet. Sci. Lett., 200, 191-205.

R. E. Came, Division of Geological and Planetary Sciences, California Institute of Tech- nology, Pasadena, CA 91125, USA. (rcame@gps. caltech.edu)

W. B. Curry and D. W. Oppo, Department of Marine Geology and Geophysics, Woods Hole Oceanographic Institution, Woods Hole, MA 02543, USA.

J. Lynch-Stieglitz, School of Earth and Atmospheric Sciences, Georgia Institute of Technology, Atlanta, GA 30332, USA. 